\title{
The Effect of Political Instability on Travel Movement in Ptolemaic Egypt
}

\author{
By Heba Magdy*
}

This paper shines light on the political instability in Egypt during the Ptolemaic period that was mainly caused by three factors: the struggle for the throne, as in the case of the struggle of the two brothers Ptolemy VI and Ptolemy VIII, the king's weakness because of the rule of a Child-King and the Egyptian revolts that mainly broke out in Upper Egypt. This political unrest affected the travel movement in three main issues: tourism, trade and political delegations. For example, Egypt witnessed a flood of travellers keen on sightseeing in Egypt. However, this travel stopped during the revolts. This can be proved by the absence of the graffiti and the inscriptions in certain periods. It seems that trade was negatively affected precisely that with Nubia that led to the end of the elephant-hunting expeditions. Political instability led to changing the trade route to India. As for the political delegations, they increased as a result of political instability and the interference of Rome in the internal affairs of Egypt.

\section{Introduction}

Ancient Egypt's stability was the reason for the great civilization that lasted for more than 3000 years. Therefore, the ancient Egyptians created a sign for the stability which is the Djed Pillar. The ancient Egyptian artisans were very keen on representing the importance of stability. Therefore, many scenes represented the kings raising the Djed pillar "symbol of stability" in front of the gods as a metaphor for the stability of the monarch. The ancient Egyptian kings were very keen on securing the stability of the country on all aspects: the administrative system, the religion, economic status, and the army. The Ptolemaic kings followed the steps of the Pharaohs in maintaining the stability of the regime. They adopted the same administrative system that was based on the divine kinship with limited changes. They also maintained the same Pharaonic pantheon, as they were represented in the scenes worshipping such gods. They were also keen on gaining the supports of the priests by offering them some privileges. Therefore, Egypt maintained its stability in the first three centuries of Ptolemaic rule. Later, some reasons led to the weakness of the kingdom, which affected the stability of the country. The researcher will give an account on the reasons for such weakness and then discuss its impact on the travel movement.

* "Associate Professor, Faculty of Tourism \& Hotels, Alexandria University, Egypt. 


\section{Literature Review}

Previous studies discussed the history of the Ptolemaic kingdom and mentioned the reasons for the decline of this kingdom: Holbl (2001) A History of the Ptolemaic Empire. Other studies were interested in the travel movement in Graeco-Roman Egypt. For example, there are several studies concerning Tourism, such as: Milne Grafton (1916) Greek and Roman Tourists in Egypt. Rostovtzeff M. (1928) Greek sightseers in Egypt. Hohlwein N. (1940) Deplacements et Tourisme dans l'Egypte Romaine. Foertmeyer (1989) Tourism in Graeco-Roman Egypt. Nevertheless, these studies mentioned the evidences proving the existence of such a movement in Egypt, without giving an evident analysis concerning the effect of the political instability of the country on such a movement. Thus, the researcher examined such studies, in addition to the studies that dealt with the graffiti, to prove the effect of political stability on tourism during Ptolemaic Egypt.

As for trade, many other studies dealt with it in Egypt during the GrecoRoman period, such as: Casson (1993) Ptolemy II and the Hunting of African Elephants, Debborah D. (2004) Egyptian Red Sea trade: An international affair in the Greco-Roman period, Sidebotham (2011) Berenike and the Ancient Maritime Spice Route, Fauconnier B (2012) Graeco-Roman merchants in the Indian Ocean. However, no study proved any connection between the political instability and the attempts done to secure the trade route and the stop of the Elephant-hunting expeditions.

Concerning the foreign delegations, all the studies sufficed by mentioning them without inferring to the increase of these delegations starting from the $2^{\text {nd }}$ century $\mathrm{BC}$ that occurred as a result of the political instability of the country.

\section{Methodology}

The researcher collected relevant data from the specified documents to analyse the material and arrive at a more complete understanding of the impact of the political instability on the travel movement relying mainly on the graffiti and the inscriptions, the papyri, and the commentaries of the historians. Depending on the analysis of the compiled data, the researcher was able to shed light on the following questions:

- Was there any link between the absence of inscriptions during certain periods and the political status of the country at that time?

- Did the political instability affect the trade route?

- Could the political instability be considered as the reason for the increase of delegations at that time? 


\section{An Account for Political Instability}

Ptolemaic Kingdom faced a decline in the $2^{\text {nd }}$ century BC related to certain political causes:

The Struggle for the Throne

After the death of Ptolemy $\mathrm{V}$, a power struggle occurred between the two brothers Ptolemy VI and Ptolemy VIII which definitely weakened the country to the point that led the ruler of Syria Antiochus IV to invade Egypt. Another struggle occurred latterly between Ptolemy VIII and his sister Cleopatra II that also weakened the country and led to a civil war in addition to the struggle between Ptolemy IX and his brother Ptolemy X, and the famous "The Alexandrian War" ${ }^{1}$ war between Ptolemy XIII and his sister Cleopatra VII.

\section{The Weakness of the King}

The death of Ptolemy IV leaving a seven-year-old child to rule the country led the royal court (Sosibius and Agathocles) to set a conspiracy to kill the mother Arsinoe III to gain custody of the child. It should be pointed out that the murder of Arsinoe III is conjectural, as both her death and that of Ptolemy IV were not mentioned directly in the historical sources. However, historians only mentioned her sudden death, and the arrangements done by Agathocles to announce himself as the guardian of Ptolemy V. ${ }^{2}$ The scholars assumed that her death has been a murder at the behest of Sosibius.

Ptolemy VI also died, leaving the throne to a child (Ptolemy VII) under the custody of his mother Cleopatra II. This led Ptolemy VIII to kill Ptolemy VII and gain the throne of Egypt. Ptolemy XII died, leaving the throne to a child (Ptolemy XIII) under the custody of his older sister (Cleopatra VII).

\section{The Revolts}

Starting from the $2^{\text {nd }}$ century BC, the Egyptians started to revolt against the Ptolemaic rule because of the decline in the economic status that obliged the government to raise the tax rates. There were taxes on every single aspect of daily life, for example: Police-tax, the veil-tax for women, guardtax, beer-tax, taxes on the contracts. There was also the salt tax that was issued during the reign of Ptolemy IV and was paid monthly. ${ }^{3}$ In addition to the cruelty in collecting the taxes. ${ }^{4}$ This was revealed in a papyrus by a man

1. G. Holbl, A History of the Ptolemaic Empire (London: Routledge, 2001), $194 \mathrm{ff}$.

2. Polybius 15.25 .

3. S. LeRoy Wallace, "Census and Poll-Tax in Ptolemaic Egypt," The American Journal of Philology, 59, no. 4 (1938): 418-442.

4. M. Harper, "Tax contactors and their relation to tax collection in Ptolemaic Egypt," Aegyptus 14(1934): $50 \mathrm{ff}$. 
who was accused of not paying the taxes complaining of mal and violent treatment. The papyrus dates to the reign of Ptolemy V:

"To Protarchos, the epimeletes, from Menches, the goldsmith of the Oxyrhynchites in the division of Polemon. After Ptolemaios, tax farmer of the goldsmiths' tax for the nome, found me in Krokodilopolis and made accusations against me (although I owed nothing to the king) and took with him as a helper Menelaos, a police officer, and they led me off and treated me violently and took away from me the silver lump that I had under the contract and the necklace, for which things the weight is 108 drachmai, for which the documents will be attached, I appeared against them before Asklepiades, your agent, and they agreed and said they would return the things, but as of this hour they have not given them back. And since I am being harassed by the owner of the silver I am not able to leave town but am being destroyed since I am idle. Therefore, in order that I be able to pay the taxes owed to the royal bank in full, I ask and beseech you to send for them and to force them to give back the silver to me. For, when this is accomplished, I, who participate in the tax farming operations of the state, will not be done injustice, but will have received help. Farewell". 5

There was also a social stratification in Egypt during the Ptolemaic period, in which the Egyptians were considered the lowest strata of the society. They were deprived of holding governmental positions. There are few evidences from the papyri referring to this ethnic tension between the Greeks and the native Egyptians. There is an appeal from the second century $\mathrm{BC}$, made by a man called Ptolemaios (son of a Macedonian father and an Egyptian mother) to Greek civic officials, saying:

"For in year 19, on Phaophi 11, being present at the Astartieion, in which temple I am now in katochê, they (Egyptians) broke in, wishing to strip and insult me, just as previously they attempted to get rid of me (?), in spite of the fact that I am a Greek". ${ }^{6}$

The first revolt occurred during the reign of Ptolemy III when he was involved in the third Syrian war, the matter that made the king return to Egypt to solve these problems. The deeds of the king were retained in the Canopus decree. ${ }^{7}$ It seems that the real effective revolts were those that occurred starting from the reign of Ptolemy IV. This revolt started in the Delta in 216 BC and reached Thebes in $207-206$ BC. It resulted in the independence of the Thebaid region and the fall of the Dodecaschoenus

\footnotetext{
5. P. Mich.18.774

6. UPZ 1.7.

7. OGIS 56.
} 
under the Kushite supremacy. The revolt continued till the reign of Ptolemy $\mathrm{V}$ who succeeded in crushing it in $186 \mathrm{BC}{ }^{8}$

During the reign of Ptolemy VI three revolts occurred: one in Alexandria in $165 \mathrm{BC}$, headed by a Greco-Egyptian man called Dionysius Petosarapis. Another revolt took place in El-Fayoum, and a third one in the Thebaid region in $168-164 \mathrm{BC}$. Ptolemy VI was capable of crushing these revolts. ${ }^{9}$ At the beginning of the reign of Ptolemy VIII, he married Cleopatra III (daughter of Cleopatra II) without divorcing the mother, in addition to the attitude that he took towards the Alexandrians by expelling the intellectuals out of it. This aroused the anger of the Alexandrians who set fire to the royal palace in 131 BC. Ptolemy VIII, Cleopatra III and their children escaped to Cyprus. Meanwhile, Cleopatra II and her son Ptolemy Memphitis acclaimed as king. However, Ptolemy VIII was able to reach the boy and kill him. Ptolemy VIII in Cyprus got together a mercenary army to continue the war against his sister in Egypt. Cleopatra II reigned as a sole king in $132 \mathrm{BC}$ and was entitled Soteria. Ptolemy VIII was trying to regain his power over Egypt. A civil war was set, as the Alexandrians supported Cleopatra while the countryside supported Ptolemy VIII. Ptolemy VIII began to take command of Upper Egypt and in 129 BC he had succeeded in regaining Alexandria by a military victory. Cleopatra II escaped to Syria in 127 BC. $^{10}$

During the reign of Ptolemy IX many revolts occurred. The first one was by the Alexandrians, who accused him of trying to kill his mother Cleopatra III. This revolt ended with the escape of Ptolemy IX to Cyprus in 107 BC. When Ptolemy IX regained his throne, another revolt occurred in Thebes in $88 \mathrm{BC}$ and lasted for three years and caused destruction to the region. ${ }^{11}$ The reign of Ptolemy XII faced also some revolts: one was taken by the Alexandrians in $58 \mathrm{BC}$ and ended with the escape of the king to Rome. The second one took place after the return of Ptolemy XII to the throne. It was done against the Roman Praefectus Rabirius. ${ }^{12}$

\section{The Effect of Political Instability on the Travel Movement}

All the above-mentioned factors had a noticeable impact on the travel movement during the Ptolemaic era. The researcher here will deal with this impact on three main issues.

8. M. Alliot,"La Thebaide en lute contre les rois d'Alexandrie sous philopator et Epiphane (216 - 284)" ["The Thebaide in fight against the kings of Alexandria under Philopator and Epiphane (216 - 284)"], RBPH 29(1951): 421 - 443.

9. C. Preaux, "Esquisse d'une histoire des revolutions egyptiennes sous les Lagides" ["Sketch of a history of Egyptian revolutions under the Lagides"], CdE 11(1936): 538 - 542.

10. G. Holbl, A History of the Ptolemaic Empire, $194 \mathrm{ff}$.

11. M. Della Monica, Les derniers pharaons: les turbulent Ptolemees: d'Alexandre le Grand a Cleopatra [The last pharaons: the turbulent Ptolemees: from Alexander the Great to Cleopatra] (Paris: Maisonneuve et Larose, 1993), 103.

12. G. Holbl, A History of the Ptolemaic Empire, 227. 
Trade

Ancient Egypt traded goods with other countries such as Nubia, Asia Minor, Libya, Mesopotamia and Arabia. During the late period the Egyptian trade was in the hands of the Phoenicians and Greeks. The government was eager to secure the trade routes precisely the desert routes. During the Ptolemaic period, Egypt traded with countries that were already under the Ptolemaic rule such as: Cyprus, Syria, Nubia and Cyrene. Moreover, they traded with other foreign areas such as: the Aegean Sea, Rome, south Arabian cities and Punt.

Trade with Upper Nubia aimed at transporting ivory and war elephants to confront the Syrian enemy that used the Asian elephants in their wars. There were elephant-hunting stations along the Red Sea coast. The ships that used to carry those elephants were called "elephantegoi". The elephanthunting expeditions started during the reign of Ptolemy II, who established also ports on the Red Sea to be the base for shipping the elephants. The bases are Phiotera and Ptolemais Theron. Later on, Berenice Troglodytica was established between the previous two bases. The Ptolemies extended the roads and wells to reach these harbours. ${ }^{13}$ African elephants were offloaded at the Red Sea port and started their journey across the Eastern Desert to reach river ports on the Nile valley (Fig. 1). The journey lasted for nearly two weeks, and it was accompanied by guards. At the Nile ports, the elephants were transferred onto large barges to Alexandria in preparation for battle training. There were some graffiti that were found relating to such expeditions during the reigns of Ptolemy II, III and IV. Moreover, there is graffiti that mentioned the names and hometowns of some Ptolemaic-era elephant hunters. These graffiti were engraved on the rocks of the eastern desert. Examples can be seen at El-Kanais (a place in Wadi Mia, in the eastern desert) where the travellers of the trade route or the elephant-hunting expeditions, wrote their names and paid tributes to god Pan for a safe return from desert travel. ${ }^{14}$ The commentaries of historians also described the Ptolemaic battles in which numbers of elephants are listed. ${ }^{15}$

13. L. Casson. "Ptolemy II and the hunting of African elephants," Transactions of the American Philological Association, 123(1993): 248-249.

14. R. Mairs, "Egyptian inscriptions and Greek graffiti at El Kanais in the Egyptian Eastern desert," in Ancient Graffiti in Context, ed. J. Baird and C. Taylor (London, 2010), 153-164.

15. S.E. Sidebotham, Berenike and the ancient maritime spice route (Berkeley/Los Angeles/London:California University Press, 2011), 41-46. 


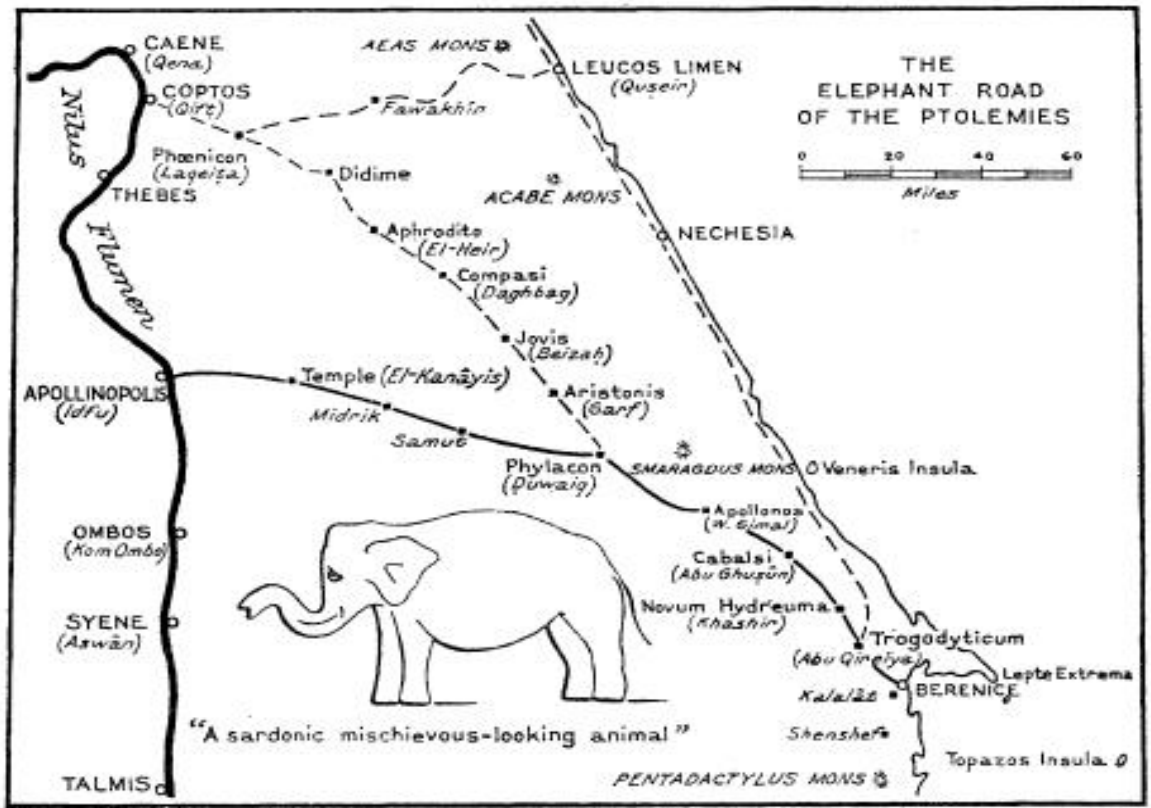

The Elephant Road of the Ptolemies. The elephant is copied from Weigall (1909). Plate xxxi; a graffito by Dorion

Figure 1. The Elephant Road of the Ptolemies

Source: G. W. Murray and E. H. Warmington, "Trogodytica: The Red Sea Littoral in Ptolemaic Times," The Geographical Journal 133, no. 1(1967): 29.

Through examining the graffiti and the commentaries of the historians, it seems that they all date back to the first reign of the Ptolemies. We can infer that these expeditions stopped after the battle of Raphia. Some scholars thought that the end of the elephant-hunting expeditions could be due to the recognition of the cleverness of the Indian elephants over the African ones; assuming this was the reason, why it took so long for the Ptolemies to recognise such a fact. Thus, the researcher suggests that the revolt that occurred during the reign of Ptolemy IV and lasted till the reign of Ptolemy $\mathrm{V}$, prompted to the interruption of the trade along the Nile between Egypt and Nubia, especially that the Thebaide region declared its independence and the Dodecaschoenus fall under the Kushite supremacy. When Ptolemy $\mathrm{V}$ regained his power over the Dodecaschoinos region and extended the frontiers to the Second Cataract, the elephant-hunting expeditions continued. There is a Ptolemaic officer called Kharimortos attained in Cape Gardafui around $200 \mathrm{BC}$, and that probably established the furthest hunting base. ${ }^{16}$ This didn't last, as by the end of the second century BC the frontiers stood at the southern end of the Dodecaschoinos, north of Hiera Skymnos, and by the end of Ptolemaic rule, the frontier had been once more withdrawn to Syene. ${ }^{17}$ This decline occurred because of political instability in the Ptolemaic kingdom, and led to the end of the trade with Nubia.

16. P. Schneider, "Before the Somali Threat: Piracy in the Ancient Indian Ocean," The Journal of the Hakluyt Society (July, 2014): 2.

17. G.M. Cohen, The Hellenistic Settlements in Syria, the Red Sea Basin, and North Africa (Berkeley, Los Angeles and London: University of California Press, 2006), 48. 
It's worth mentioning also that because of the instability that occurred in Upper Egypt, Ptolemy V Epiphanes protected the travel movement in the Nile, the sailors and people, using Egyptian soldiers (Naukleromachimoi). This system continued throughout the Ptolemaic period, as long as the internal disturbance continued in the country. There is an inscription engraved on a stela that dates back to $130 \mathrm{BC}$, preserved in the Museum of Alexandria (Inv. N. 41) that refers to such soldiers, where we can read:

"On behalf of king Ptolemaios and queen Cleopatra his wife, the gods Euergetai, and their children; Soterichos of Gortyn, the son of Ikadion, one of the chief bodyguards, who was sent by Paōs the kinsman and strategos of the Thebaid, for the collection of precious stones and to oversee the sailings and to provide security for those who are transporting cargoes of frankincense and other valuable gifts from the mountain at Koptos, (dedicated this stela) to Pan Euodos ["of good journeys"] and all the other gods and goddesses; in the 41st year, on the 10th day of Thoth". 18

In the Ptolemaic security system, we have the phylakitai that had a regular and important task of serving as guards on board ships. Those who were selected for this task were required to submit oaths of office before receiving sealed samples of their ship's cargo. There were also the nauphylakes who served as ship guards. ${ }^{19}$ There was also a special troop of soldiers whose duty was patrolling the Nile on police boats, known as potamophylakes. They played an important role in securing the Nile boats during the political instability that occurred in Upper Egypt. ${ }^{20}$

The trade to the East was of great importance during the Ptolemaic period. The Ptolemies used to import myrrh, calamus, saffron, cassia, cinnamon, textiles, woods, precious and semi-precious stones. The ancient sources referred to three main trade routes: The Northern route that led from Middle Asia to the Black Sea and the Bosporus, the middle route that connects India with Seleucia in Pieria, and the Southern route that connects India with the Sea-Port of Aden on the Red Sea. The middle route was the most important during the third century BC. When Ptolemy V lost control of Coele-Syria, this made the Seleucids take control of the middle route. Thus, the Egyptians were compelled to use the southern sea-route to trade with India. They depended also on the same ports that were previously used as a base for shipping the elephants.

The first direct voyage by a Greek to India was done in 118 BC (reign of Ptolemy VIII) by the Greek Navigator Eudoxus of Cyzicus. Strabo mentioned that a Ptolemaic navy patrol in the Gulf of Aden discovered the remains of a strange ship and rescued a starving Indian sailor. They took

18. W. Dittenberger, Orientis Graeci Inscriptiones Selectae. 2 vols. Leipzig 1903-1905, 132.

19. J. Bauschatz, Law and Enforcement in Ptolemais Egypt ( New York: Cambridge, 2013), 284-286.

20. T. Krause, "The Nile Police in the Ptolemaic Period,", The Ptolemies, the Sea, and the Nile, ed. K. Buraselis, M. Stefanou (Cambridge, 2013), 172-184. 
him to the court of Ptolemy VIII. Later, this man learned Greek and informed the Ptolemaic court that his vessel was blown off course on a trade sailing from India. He served as a guide for the Greek sailors who return him to India. ${ }^{21}$ It seems that only few Greek ships dared to travel on this direct route to India because of the threat of storm and piracy, as other merchants sufficed by reaching the port of Aden where they acquire the Indian goods from the visiting Eastern traders. ${ }^{22}$ Strabo confirmed this, saying:

"In these times, not even 20 vessels would dare to sail into the Gulf of Aden far enough to glance outside these straits". ${ }^{23}$

"Under the Ptolemaic kings only a few vessels would sail to India and carry back Indian merchandise". ${ }^{24}$

Ancient sources refer to the battles that occurred between the Ptolemies and the Nabataean pirates in the Red Sea who preyed on their shipping. The Nabataeans may also have raided the Egyptian Red Sea coast. Therefore, the Ptolemies placed archers aboard some of their vessels as protection. ${ }^{25}$ These raids were mentioned by Strabo:

"and these Nabataeans formerly lived a peaceful life, but later, by means of rafts, went to plundering the vessels of people sailing from Egypt". ${ }^{26}$

The same is mentioned by Diodorus Siculus:

"After one has sailed past this country the Laeanites Gulf comes next, about which are many inhabited villages of Arabs who are known as Nabataeans................ Now in ancient times these men observed justice and were content with the food which they received from their flocks, but later, after the kings in Alexandria had made the ways of the sea navigable for the merchants, these Arabs not only attacked the shipwrecked, but fitting out pirate ships preyed upon the voyagers, imitating in their practices the savage and lawless ways of the Tauri of the Pontus; sometime afterward, however, they were caught on the high seas by some quadriremes and punished as they deserved". ${ }^{27}$

To conclude, the political instability in the Ptolemaic Kingdome affected trade negatively. It led to the stop of specific trades such as the elephant hunting expeditions, and furthermore the change of certain trade routes such

21. Strabo2.3.4-5.

22. R. McLaughlin, Rome and the Distant east: trade routes to the ancient lands of Arabia, India and China (Bloomsbury Academic, 2010), 24 - 25.

23. Strabo17.1.13.

24. Strabo2.5.12.

25. S.E. Sidebotham, Berenike and the Ancient Maritime Spice Route, 35.

26. Strabo 16.4.18.

27. Diod..3.43.4. 
as the trade route to India. Therefore, the Ptolemies were keen on providing the required protection by appointing guards to protect the ships from any raids.

\section{Tourism}

Tourism means those who travelled to visit the ancient monuments either from other cities inside Egypt or from outside countries. By examining the graffiti that was found inscribed on the ancient monuments by visitors, it seems that Upper Egypt didn't gain considerable attention during the Ptolemaic period. The researcher examined the graffiti found in the Valley of the Kings that were gathered by Baillet. A few graffiti dating back to the Ptolemaic period were found. The oldest graffiti dates to year $278 \mathrm{BC}$ (reign of Ptolemy II) and is engraved on the walls of the tomb of Ramses X. ${ }^{28}$ It reads:

"Euphranor, son of Philon, the Rhodian, under Ptolemy son of Ptolemy, year 7, month of Panemos".

Another graffiti is from the tomb of Ramses IV dating back to year 45 $\mathrm{BC}$ (reign of Cleopatra VII) made by a man from Mysia (a region in the north west of Asia Minor); it was located on the south coast of the Sea of Marmara.

"Hipparchos, son of Menedeme, Mysian, I came in year 45, the $25^{\text {th }}$ of Payni" 29

It is noticeable that starting from the reign of Ptolemy II till the reign of Cleopatra VII, no evidences for visits to the Valley of the Kings were found. The researcher related this to the various revolts that occurred in this region starting from the reign of Ptolemy III, besides the period of independence that occurred in Thebes during the reign of Ptolemy IV. Later, visits to the tombs increased precisely during the Roman era.

The temple of Seti I at Abydos was regarded as a place of healing. Sufferers gathered in the corridors and halls of the Temple of Seti I, making humble pleas to god Sarapis (who was assimilated with Osiris at that time) for health and fertility. Probably the therapy was done there through the incubation, as it was utilized to be done in the temples of Sarapis at Memphis and Canope. In the incubation, a night was passed in a room of the temple, during which the god appeared to the patient in his dream. When awakening, he found himself cured. ${ }^{30}$ By examining the Graffiti that were

28. J. Baillet, Inscriptions Grecques et Latines des tombeaux des rois ou syringes à Thebes, MIFAO: Tome XLII face.2-3 (Cairo, 1924), XX, no 30, 66.

29. J. Baillet, Inscriptions Grecques et Latines des tombeaux des rois ou syringes à Thebes [Greek and Latin inscriptions of the tombs of kings or syringes in Thebes], no. 670 .

30. P. Perdrizet and G. Lefebvre, Les grecs au temple d'Abydos [The Greeks at the Temple of Abydos], Journal des Savants 19, no. 4(1921): 145 - 156. 
gathered by Perdrizet \& Lefebvre, the researcher found that most of the Greek graffiti date back to the $2^{\text {nd }}$ century $\mathrm{BC}$; and that there is no specific date given to these graffiti. Thus, it would be difficult to emphasize whether the visits to the temple stopped during the revolts or not. Among all the graffiti, there is just one that carries a definite date related to the reign of Ptolemy IV. It seems that the Ptolemaic army that engaged in the siege of the city of Abydos, during the revolt that occurred in the reign of Ptolemy IV, took advantage of being in the vicinity of the temple of Seti I and paid tribute to Serapis. This graffito was found engraved on the walls of the temple. It reads:

"I am Philocles son of Hierocles, from Trezene, I came to worship god Serapis during the siege of Abydos, year 6, day 28 of Baoona".

Philocles of Troizen (a city in the Peloponnese) honours the local god Sarapis (Osiris). Philocles took part in the siege of Abydos in 199 BC on the side of Ptolemy V. ${ }^{31}$

The island of Philae was used also to gain the attention of the visitors. The reason that made these people anxious to visit the island was to pay homage to Isis, the main goddess of the temple. Other pilgrims were very keen on visiting the island during the annual festival of Isis. Some scholars thought that during this festival, the statue of the goddess was brought out of the sanctuary and there was an oracle practiced there. ${ }^{32}$ Although there are some graffiti that mentioned these ceremonies, there is no mention of a practice of the oracle. Inscriptions found engraved on the island and collected by Bernard A. proved the existence of tourists starting from the reign of Ptolemy II till the reign of Ptolemy VI. The tourists came from Cyrene, Thessaly, Crete and Aspendus. ${ }^{33}$ There are likewise other inscriptions in Latin left by Romans dating back to the same period. ${ }^{34}$ However, the researcher noticed that during the independence period that occurred in Thebes during the reign of Ptolemy IV till it ended in the reign of Ptolemy $\mathrm{V}$, no records of visits were found.

The researcher assumed that the Meroetic people should have come and visited the temple at that time, although there is no record of such visits. The researcher based her theory upon the importance of the Isis cult in Nubia as early as the Pharaonic period. It seems that Isis was part of the pantheon of the Nabatean Kingdom; the annals of king Harsiyotef (first half of the fourth century BC) confirm her inclusion among state cults by reporting festivals celebrated during his first thirty-five ruling years. Later, The Meroitic rulers respected the Napatian heritage and increased the relevance of Isis, as they

31. P. Perdrizet and G. Lefebvre, Les graffites grecs du Memnonion d'Abydos(Paris, 1919), no 32 pis.

32. E. Revillout,"Letter upon Nubian Oracles," PSBA, vol. 10(1888): 55 - 59.

33. A. Roccati, "Iscrizioni Greche di File" ["Inscriptions of Greek File"]. In Scritti in onore di O. Montevecchi, ed. O. Montevecchi and E. Bresciani (Bologna, 1981), 329 - 333.

34. A. Roccati, "Nuove epigrafi greche e latine da File" ["New Greek and Latin inscriptions from File"], in Hommages a Maaren Vermaseren, ed. M. De Boer and T. Edridge, EPRO 68 (Leiden, 1978), 988 - 996. 
made her the consort of a well-known Nubian god "Apedemak". the Meroitic rulers often bear the title of "Son of Isis" or "beloved of Isis" such as king Arnekhamani $\left(3^{\text {rd }}\right.$ century $\left.\mathrm{BC}\right)$. On the walls of the temple of Musawwarat Es-Sufra, Isis appeared protecting king Arnekhamani, while prince Yerkie is designated "The priest of Isis". King Ergamenes also offered to Isis twelve Schoenoes of land on each side of the river from Aswan to Takompso. ${ }^{35} \mathrm{We}$ can't ignore also the terracotta statuette from the $2^{\text {nd }}$ century BC that represents a female Nubian attendant of Isis of Philae, depicted in a kneeling position. This statuette indicates the participation of the Meroites in the cult of Isis at Philae. ${ }^{36}$ Thus, the researcher assumes that when Philae (the main cult center of Isis) was seized by the Meroitic kings, the Meroities should have seized the opportunity to visit such a place. there are already evidences from later periods (Roman era) concerning the Meroitic pilgrimage to Philae that appeared on the walls of the temple of Isis; where the inscriptions (written in Demotic, Greek, Meroitic) mention the festivals in which the Meroites participated as well as the rich gifts of gold brought from the kings in Meroe. ${ }^{37}$

There are likewise some inscriptions of the Kushite kings engraved on the temple of Philae. The Kushite king Ergamenes II completed the building of the temple of Arsenophis on the island of Philae that was initiated by Ptolemy IV. After the crushing of the revolt in 186 BC, the names of the Meroitic king Ergamenes II were mutilated or adapted for Epiphanes. ${ }^{38}$ No records of visits could be found also during the revolts that took place during the reign of Ptolemy VI.

Records of visits can be seen proceeding from the reign of Ptolemy VIII, but when the civil war between him and Cleopatra II started, the visits stopped. Despite the official reconciliation between Cleopatra II and Ptolemy VIII in $124 \mathrm{BC}$, the country didn't immediately return to a peaceful and orderly bureaucratic government. The fights which had been going on in many places between the two factions had brought about a state of violence and confusion which could not be ended all at once. The papyri informed us about the conflict that occurred in Upper Egypt between the districts. P.Bad.III. N 48 informed us about a struggle between Hermonthis and Crocodilopolis in 123 BC. PSI. III, N 171 mentioned disputes in Thebes in $122 \mathrm{BC}$. It seems that the tourists started to visit the island after the amnesty decree that was made by Ptolemy VIII in 118 BC. It seems that starting from this time onward, the island of Philae witnessed flows of pilgrims. Therefore, the priests of Isis sent a letter to the king, complaining about the high-ranking civil servants, who used to do the pilgrimage

35. M. Baldi, "Isis in Kush, a Nubian soul for an Egyptian goddess," Journal of Intercultural and Interdisciplinary Archaeology2 (2015): 97-121.

36. L. Torok, Between two worlds. The frontier region between ancient Nubia and Egypt 3700 BC-AD 500 (Leiden-Boston: Brill, 2009), 1-6.

37. S. Bumbaugh, "Meroitic worship of Isis at Philae," in Egypt in its African Context, Proceedings of the conference held at The Manchester Museum, University of Manchester, 2-4 October 2009, ed. Karen Exell, (England, 2011), 66-69.

38. E. Winter, "Ergamene II, seine Datierung und seine Bautatigkeit in Nubien" ["Ergamene II, his dating and his building activity in Nubia"]. MDAIK 37 (1981): 512. 
accompanied by their families, and their abuses to the priests, who were obliged to take care of the expenses of their maintenance. This complaint is engraved on the obelisk that was placed in front of the temple of Isis (later transported to Kingston Hall in London):

"To the king Ptolemy, to the queen Cleopatra, his sister and to the queen Cleopatra, his wife, the Evergetes gods, we address our salute, we the priests of Isis adored in the Abaton and at Philae, the very great goddess:

waited that the people of passage to Philae, strategists, epistates, thebarchs, royal clerks, chief of policemen, all the other civil servants, the troops that come with them and the remainder of their following, compel us to pay the expenses of their maintenance, while they are here, and by reason of this practice the temple is becoming very poor and we're in danger of coming to possess nothing for the sacrifices and the libations that we made for you and your children.

We implore you, very great gods, to order, if you please, to Noumenios, the parent of the king and the epistolographer, to write to Lochos, the parent of the king and strategist of the Thebaide, not to exercise these vexations to our consideration, nor to allow anybody else to make it, and to give us the permission the raise a stele, on which we'll transcribe the goodness that you show towards us at this opportunity, so that your favor always stays noteworthy, at Isis, for evermore". ${ }^{39}$

This inscription dates to the reign of Ptolemy VIII (between 124 and $116 \mathrm{BC})$. In response to this letter, the king ordered to take this complaint into consideration and threatened everyone who wanted to make vexations to the priests of Philae.

Visitors to the temple continued till the end of the Ptolemaic period because there was no trouble that occurred in this region during this period; all the trouble was in Alexandria. The visitors left proskunemata on the walls of the temple. On the southern pylon, there are graffiti that date back to the year 116 BC (reign of Ptolemy IX Soter II).

"Me, Achilleus, son of Demetrius, I came nearby our lady Isis, the second year, the month of Mechir" 40

On the same pylon, there is a graffiti which dates to the reign of Ptolemy X Alexander I. Here, the pilgrim dedicated his act of worship to his wife, his mother and his brothers, and wished that they'll be in happiness.

"Me, Epiodoros, I came to find our lady Isis of Philae, and I made this act of worship to my brothers, my wife, and my mother, in pledge of happiness, the $20^{\text {th }}$ year". 41

39. A. Bernard, Les inscriptions grecques de Philae [The Greek inscriptions of Philae], Tome I (Paris, 1969), 160 - 196, no 19.

40. A Bernard, Les inscriptions grecques de Philae, 207 - 208, no 21. 
It is apparent that the period of peace that was made by Ptolemy VIII was the reason for the flood of pilgrims to the shrine of Imouthes that was constructed by the same king in the temple of Deir el-Bahari. This sanctuary seems to have become a regular resort for patients who scratched or painted numerous invocations in Greek to these deities on the walls of the temple. There is also no exact date for the graffiti inscribed on the walls of this sanctuary. ${ }^{42}$ However, the researcher assumes that the visits continued till the end of the Ptolemaic period as occurred in Philae. The visitors also left proskunemata:

"The Macedonian Andromachos, a salaried traveler, came close to Amenothes, the beneficent god. He felt sick and the god rescued him on the same day. Be you well." ${ }^{43}$

To conclude, trouble in Upper Egypt affected the cultural tourism that aims at visiting the historical sites such as the Valley of the Kings that lacks any graffiti starting from the reign of Philadelphus till the reign of Cleopatra VII. Meanwhile, the pilgrims to the religious sites such as the temple of Isis at Philae or to the therapeutic sites such as the temple of Abydos and the temple of Deir el-Bahari, stopped only during the revolts but once the revolt was crushed, the pilgrimage continued.

In addition to the trouble that faced tourism in Upper Egypt because of the revolts that occurred in this region, Alexandria was not away from the trouble. It is obvious that because Alexandria was the capital of the Ptolemaic kingdom, it faced an instability caused by the struggle that occurred on the throne between the kings. This of course affected the visits to the Serapeum of Alexandria that was seen as an important pilgrimage destination. This temple was accessible to all and was open all day long to receive its devotees who would like to fulfill such rites and offer any good wishes to be bestowed upon their beloved. They perhaps poured libations on an altar or burnt some incense. There was probably a necessity of going around the temple or the altar, three or seven times or at least whispering some rituals and uttering some phrases to inspire some good wishes or to avert the evil eye. ${ }^{44}$ Examining the graffiti of the visitors that were found in Alexandria $^{45}$, revealed the absence of any inscription starting from the reign of Ptolemy VI till the reign of Cleopatra VII.

41. A Bernard, Les inscriptions grecques de Philae, 222 - 223, no 28.

42. A. Bataille, Les inscriptions grecques du Temple de Hatshepsout á Deir el-Bahari [The Greek inscriptions of the Hatshepsut Temple in Deir el-Bahari], publication de la societe Fouad I de Papyrologie X (1951). 30 , no 48

43. A. Bataille, Les inscriptions Greque du Temple de Hatshepsout ó Deir el-Bahari,

44. A. Zaki,"The popularity of the Sarapis cult as depicted in letters with proskeynema formula," in Etud Pap., 9(1971): 187.

45. E. Bernard, Inscriptions Grecques d`Alexandrie Ptolémaïque [Greek Inscriptions of Alexandria Ptolemaic] (IFAO, 2001). 


\section{Diplomatic Delegations}

The land of Egypt witnessed the arrival of different diplomatic delegations during the Ptolemaic period. Before the second century BC, the emissaries' intentions were either religious or political. The earliest foreign emissaries to Egypt were the Rhodians, who reached Egypt to obtain an oracular response from Amun of Siwa concerning honoring Ptolemy I. This visit is mentioned by Diodorus Siculus:

"In the case of Ptolemy, since they wanted to surpass his record by repaying his kindness with a greater one, they sent a sacred mission into Libya to ask the oracle at ammon if it advised the Rhodians to honour Ptolemy as a god. Since the oracle approved, they dedicated to him, in the city, a square precinct, building on each of its sides a portico a stade long, and this they called the Ptolemaeum". ${ }^{46}$

As for the political emissaries, they came to Egypt to gain the support of the house of the Ptolemy to settle problems in their countries or to discuss some commercial issues. It's worth mentioning that the first Roman ambassadors in Egypt were three senators who came during the reign of Ptolemy II in response to his initiation to set an alliance between the Romans and the Ptolemaic kingdom. ${ }^{47}$ However, after the decline of the Ptolemaic rule and the rise of the internal instability, the foreign delegations (precisely the Roman) started to flood to Egypt. Nevertheless, the Egyptian delegations that were sent to Rome to gain its support cannot be ignored. The present researcher is mainly concerned with the delegations that occurred in response to the political instability in the country.

The conquest of Egypt by Antiochus IV during the reign of Ptolemy VI led some envoys to arrive in Alexandria to conclude a pacification. There were Greek envoys, two embassies of the Achaean League (composed of Alcithus of Aegium and Pasiodes), an embassy from Athens led by Demaratus, there were also Eudemus and Hicesius from Miletus, and Apollonides and Apollonius from Clazomenae. These envoys met Antiochus in Memphis, but they couldn't persuade him to retreat, as he continued to Alexandria. ${ }^{48}$ It seems that later, both Ptolemy Eurgetes and Antiochus sent delegations to Rome. The first requested the support of Rome against the Seleucids; while the latter protested that he was in Egypt to support the throne of his nephew Ptolemy Philopmetor. This is considered the earliest Ptolemaic delegation to Rome in two decades. ${ }^{49}$

Later, Roman delegations were sent and ordered Antiochus IV to leave Egypt. This delegation was headed by Popillius Laenas. Polybius told us:

46. Diod.20.100.3-4

47. R. Westall, "Rome and Ptolemaic Egypt: Initial Contacts," in Aegyptiaca et

Coptica: Studi in onore di Sergio Pernigotti, ed. P. Buzi et al. (Oxford, 2011), 349- 360.

48. Polyb.28.19-20.

49. E. Gruen, The Hellenistic world and the coming of Rome, vol. 1 (London: University of California Press, 1984), 689. 
"Popilius Laenas, the Roman commander, on Antiochus greeting him from a distance and then holding out his hand, handed to the king, as he had it by him, the copy of the senatus-consultum, and told him to read it first. But when the king, after reading it, said he would like to communicate with his friends about this intelligence, Popilius acted in a manner which was thought to be offensive and exceedingly arrogant. He was carrying a stick cut from a vine, and with this he drew a circle round Antiochus and told him he must remain inside this circle until he gave his decision about the contents of the letter. The king was astonished at this authoritative proceeding, but, after a few moments' hesitation, said he would do all that the Romans demanded. Upon this Popilius and his suite all grasped him by the hand and greeted him warmly". 50

After the death of Ptolemy VI, Ptolemy VIII the ruler of Cyrene moved to Alexandria to gain the throne of Egypt, which was occupied by Cleopatra II and her son. At that time a Roman ambassador called Thermos arrived in Alexandria, persuaded Cleopatra that she hadn't got enough army to face Ptolemy VIII, so she had to accept marrying him and let him ascend the throne of Egypt and declare her son as the heir of the throne. ${ }^{51}$ Later on, when Ptolemy VIII married Cleopatra III without divorcing the mother Cleopatra II and a civil war in Egypt was about to happen, the Roman senate sent a diplomatic delegation headed by Scipio Aemilianus to inspect the eastern provinces. This delegation reached Alexandria in $136 \mathrm{BC}$ and they were welcomed by Ptolemy VIII with a great reception. The historians who wrote about this visit made a comparison between the weakness of Ptolemy VIII and the discipline of the Romans. The envoys visited the sights of Alexandria, including the famous Pharos, and then they headed to Memphis where they were impressed by the natural resources of Egypt, particularly the Nile flood, and then returned to Alexandria. ${ }^{52}$ It seems that the aim of this visit was to estimate the enormous potential value of the country if it were governed by the Romans.

A diplomatic envoy was sent to Egypt in $112 \mathrm{BC}$ during the reign of Ptolemy IX to investigate the status of the country, especially after the struggle that occurred between the two brothers Ptolemy IX and X. This diplomatic envoy was Senator Lucius Mummius who hid the true intention of his visit and claimed that he came to Egypt as a tourist. There is a papyrus from Tebtunis, written by the royal scribe Horus to one of the high officials in El-Fayoum informing him about the visit of the Senator to the region. The papyrus reads:

"Hermias to Horos, greeting. Appended is a copy of the letter to Asklepiades. Take care that its instructions are followed. Good-bye.

50. Polyb.29.27

51. G .Macurdy, Hellenistic queens: A study of woman-power in Macedonia, Seleucid Syria, and Ptolemaic Egypt (Baltimor, 1932), 158.

52. Diod.33.28b.1-3. 
The fifth year, Xandikos 17, Mecheir 17. To Asklepiades. Lucius Memmius, a Roman senator, who occupies a position of great dignity and honor, is making the voyage from Alexandria to the Arsinoite nome to see the sights. Let him be received with special magnificence, and take care that at the proper spots the chambers be prepared and the landing-places to them be got ready, and that the gifts of hospitality below written be presented to him at the landing-place, and that the furniture of the chamber, the customary tit-bits for Petesouchos and the crocodiles, the necessaries for the view of the Labyrinth, and the offerings and sacrifices be provided; in general take the greatest pains in everything that the visitor may be satisfied, and display the utmost zeal." ${ }^{53}$

Mummius was to be shown to Petesouchos, the sacred crocodile of Arsinoe, and treats for the animal were to be provided by the priests. $\mathrm{He}$ also toured the Labyrinth, the Pharaonic temple next to the pyramid of Amenemhet III at Hawara in Fayum.

During the reign of Ptolemy XII Auletes, Alexandrian delegations were sent to Rome. This occurred when the Alexandrians expelled Auletes out of the country and he had to take refugees in Rome. When the Alexandrians heard about the attempts made by Auletes to restore his throne; they decided to send a delegation to Rome to discuss the situation with the Senate. The delegation was led by the philosopher Dion. After landing at the port of Puteoli (at Napoli), they were attacked by Auletes' assassins. Most of them were killed, while those who survived were bribed. Dion was the one who managed to escape to Rome; however, he was later poisoned. ${ }^{54}$

Thus, we can infer that the diplomatic delegations came to Egypt starting from the reign of the first Ptolemies. The presence of such delegations had no deal with the internal affair of Egypt. They had usually an intension on solving their own disputes, discussing commercial issues or strengthening the alliance between the two countries. However, the political instability that occurred later in the Ptolemaic Kingdom led to the flood of the delegations (precisely the Romans), who were involved in the disputes that occurred inside the House of Ptolemy.

\section{Conclusion}

Ptolemaic Egypt faced political instability starting from the reign of Ptolemy IV till the end of the Ptolemaic period. This instability occurred because of three main factors: the struggle on the throne, the weakness of the king, and the revolts that broke in Egypt, precisely in Upper Egypt. This political instability affected the travel movement. The revolts that occurred in Upper Egypt and the withdrawal of the southern frontier to Syene led to

53. P.Teb.I.33.

54. J. Crawford, "M. Tullius Cicero: The lost and unpublished orations, " in Hypomnemata vol. 80 (Germany : Vandenhoeck \& Ruprecht in Gottingen, 1984), 138. 
the end of the elephant-hunting expeditions that were once settled by Ptolemy II Philadelphus. It also obliged the Ptolemies to establish a security system to protect the goods transported through the desert and the Nile River till it reached Alexandria. Thus, guards were used to accompany the cargos through the desert and even on board of the transporting ships. Losing control over Syria during the reign of Ptolemy $\mathrm{V}$ affected also the trade route to India, as it obliged the Ptolemies to use the southern trade route. Moreover, the weakness of the Ptolemaic kingdom led the Nabateans to attack the Ptolemaic ships there. Therefore, the Ptolemies placed archers aboard some of their vessels as a form of protection.

If the political instability caused a step back in the trade movement in the $2^{\text {nd }}$ century $\mathrm{BC}$, it also affected the number of tourists used to visit Upper Egypt. Examining the graffiti revealed that cultural tourism had completely stopped during the Ptolemaic period and continued in the reign of Cleopatra VII. However, the pilgrimage to religious and therapeutic sites stopped only during the revolts, and continued once the revolts were crushed. Not only was tourism in Upper Egypt influenced by the political instability, but also in Alexandria where the visits to the Serapeum stopped starting from the reign of Ptolemy VI in accordance with the troubles caused by the fighting brothers.

Although the political instability led to a step back in the trade with Nubia and also in the number of tourists visiting Egypt, it led to an increase in the delegations that arrived to Egypt to solve some political issues. Although many delegations used to visit Egypt before the second century $\mathrm{BC}$, they were not driven by political instability inside Egypt but to solve their own disputes, to discuss commercial issues or to strengthen the alliance between the two countries. However, the political instability in Egypt was the cause of the visits of the Roman delegations that started with the reign of Ptolemy VI and continued till the annexation of Egypt to the Roman Empire.

\section{Bibliography}

Alliot, M. "La Thebaide en lute contre les rois d'Alexandrie sous Philopator et Epiphane (216 - 284)" ["The Thebaide in fight against the kings of Alexandria under Philopator and Epiphane (216 - 284)"]. RBPH 29 (1951): 421 - 443.

Baldi, M. "Isis in Kush, a Nubian soul for an Egyptian goddess". Journal of Intercultural and Interdisciplinary Archaeology 2(2015): 97-121.

Baillet, J. Inscriptions Grecques et Latines des tombeaux des rois ou syringes à Thebes [Greek and Latin inscriptions of the tombs of kings or syringes in Thebes]. MIFAO: Tome XLII face.2-3, Cairo, 1924.

Bataille, A. Les inscriptions Grecque du Temple de Hatshepsout á Deir el-Bahari [The Greek inscriptions of the Hatshepsut Temple in Deir el-Bahari]. Publication de la Société Fouad I de Papyrologie X, 1951.

Bauschatz, J. Law and enforcement in Ptolemais Egypt. New York: Cambridge, 2013.

Bernard, A. Les inscriptions grecques de Philae [The Greek inscriptions of Philae]. Tome I, Paris, 1969. 
Bernard, E. Inscriptions Grecques d'Alexandrie Ptolémaïque [Greek Inscriptions of Alexandria Ptolemaic]. IFAO, 2001.

Bumbaugh, S. "Meroitic worship of Isis at Philae." In Egypt in its African Context, Proceedings of the conferenceheld at The Manchester Museum, University of Manchester, 2-4 October 2009, edited by K. Exell. England, 2011.

Casson, L. "Ptolemy II and the hunting of African elephants." Transactions of the American Philological Association, 123(1993): 247-260.

Cohen, G.M. The Hellenistic settlements in Syria, the Red Sea basin, and North Africa. Berkeley, Los Angeles and London: University of California Press, 2006.

Crawford, J. "M. Tullius Cicero: The Lost and Unpublished Orations." Hypomnemata vol. 80, Germany: Vandenhoeck \& Ruprecht in Gottingen, 1984.

Della Monica M. Les derniers pharaons: les turbulent Ptolemees: d'Alexandre le Grand a Cleopatra [The last pharaohs: the turbulent Ptolemees: from Alexander the Great to Cleopatra]. Paris: Maisonneuve et Larose, 1993.

Diodorus Siculus. Library of History.

Dittenberger, W. Orientis Graeci Inscriptiones Selectae, 2 vols. Leipzig 19031905.

Foertmeyer, V. Tourism in Graeco-Roman Egypt. PhD diss. Princeton University, 1989.

Gruen, E. The Hellenistic world and the coming of Rome, vol. 1. London: University of California Press, 1984.

Harper, M. "Tax contactors and their relation to tax collection in Ptolemaic Egypt." Aegyptus 14(1934): $49-64$.

Holbl, G. A History of the Ptolemaic Empire. London: Routledge, 2001.

Krause, T. "The Nile Police in the Ptolemaic Period." In The Ptolemies, the Sea, and the Nile, edited by K. Buraselis and M.Stefanou.Cambridge, 2013.

LeRoy Wallace, S. "Census and Poll-Tax in Ptolemaic Egypt." The American Journal of Philology, 59, no. 4 (1938): 418-442.

Macurdy, G. Hellenistic queens: A study of woman-power in Macedonia, Seleucid Syria, and Ptolemaic Egypt. Baltimor, 1932.

Mairs, R. "Egyptian inscriptions and Greek graffiti at El Kanais in the Egyptian Eastern desert." In Ancient Graffiti in Context, edited by J. Baird and C. Taylor. London, 2010.

McLaughlin, R. Rome and the distant east: trade routes to the ancient lands of Arabia, India and China. Bloomsbury Academic, 2010.

Murray, G. and E. Warmington. "Trogodytica: The Red Sea Littoral in Ptolemaic Times." The Geographical Journal 133, no. 1(1967): 24-33.

Perdrizet, P. and G. Lefebvre. Les grecs au temple d'Abydos [The Greeks at the Temple of Abydos]. Journal des Savants 19, no. 4 (1921): 145 - 156.

Perdrizet, P. and G. Lefebvre. Les graffites grecs du Memnonion d'Abydos [The Greek graffiti of the Memnonion of Abydos]. Paris, 1919.

Polybius. The Histories, translated by W. Paton. Cambridge, Mass.: Harvard University Press, 1927.

Preaux, C. "Esquisse d'une histoire des révolutions égyptiennes sous les Lagides" ["Sketch of a history of Egyptian revolutions under the Lagides"]. CdE 11 (1936): $522-552$.

Revillout, E. "Letter upon Nubian Oracles." PSBA, 10(1888): 55 - 59.

Roccati, A. "Iscrizioni Greche di File" ["Inscriptions of Greek File"]. In Scritti in onore di O. Montevecchi, edited by O. Montevecchi and E. Bresciani. Bologna, 1981. 
Vol. 3, No. 3 Magdy: The Effect of Political Instability on Travel Movement ...

Roccati, A. "Nuove epigrafi greche e latine da File" ["New Greek and Latin inscriptions from File"]. In Hommages a Maaren Vermaseren, edited by M. De Boer and T.Edridge .EPRO 68. Leiden, 1978.

Schneider, P. "Before the Somali Threat: Piracy in the Ancient Indian Ocean." The Journal of the Hakluyt Society (July, 2014): 1-28.

Sidebotham, S.E. Berenike and the ancient maritime spice route. Berkeley/Los Angeles/London: California University Press, 2011.

Strabo. Geography. Perseus Project, Tufts University.

Torok, L. Between two worlds. The frontier region between ancient Nubia and Egypt 3700BC-AD 500. Leiden-Boston: Brill, 2009.

Westall, R. Rome and Ptolemaic Egypt: Initial Contacts. In Aegyptiaca et Coptica: Studi in Onore di Sergio Pernigotti, edited by P. Buzi et al. Oxford, 2011.

Winter, E. "Ergamene II, seine Datierung und seine Bautatigkeit in Nubien" ["Ergamene II, his dating and his building activity in Nubia"]. MDAIK 37, (1981): $509-513$.

Zaki, A. "The popularity of the Sarapis cult as depicted in letters with proskeynema formula." In Etud Pap. 9(1971): 165 - 219. 